\title{
Artists and Multiple Job Holding-Breadwinning Work as Mediating Between Bohemian and Entrepreneurial Identities and Behavior
}

\section{Sofia Lindström'}

PhD Candidate, Department of Culture studies (Tema Q), Linköping University, Sweden

\begin{abstract}
Artists are known to manage low income and work insecurity by holding multiple jobs. Through an analysis of interview data, this study explores the narratives of 20 visual artists in Sweden regarding breadwinning work. Positive and negative experiences of such work are analyzed in relation to the artists' work behavior and identity as either 'bohemian' or 'entrepreneurial.' Breadwinning work may be seen by artists as either enabling autonomy from the market or hindering the construction of a professional identity, depending on these behaviors/identities. However, conditions such as low wage, temporary contracts, and low control over work hours ultimately decides artist's experiences of breadwinning work. This article adds to the existing knowledge on artistic labour markets by highlighting the role of multiple job holding in mediating between an understanding of the bohemian art for art's sake artist role and the entrepreneurial role of the artist.
\end{abstract}

\section{KEY WORDS}

Artistic work / bohemian ethic / entrepreneurialism / identity / multiple job holding / narratives

DOI

10.19154/njwls.v6i3.5527

\section{Introduction}

rtists are known to be typically self-employed or working on freelance basis, developing 'portfolio careers' of either commercial or grant-based work and projects (Hausmann, 2010; Menger, 1999; Throsby \& Zednick, 2011). The consequences of the portfolio career are often pervasive insecurity with spells in and out of unemployment, as well as irregular and low income (Flisbäck, 2011; Hausmann, 2010). In order to counter this, artists typically do 'day jobs' (in Sweden often known as having 'breadwinning work') in order to sustain a living (Bain, 2005; Lingo \& Tepper, 2013; McRobbie, 2011; Menger, 1999; Throsby, 2010). Taylor and Littleton (2012: p. 120) refer to this as artists leading 'double lives'. Although artists rank among the highest in the percentage of workers with secondary jobs, there is a 'lack of any serious treatment of multiple job holding' (Menger, 1999, p. 544). Especially overlooked is the nonartistic work that is often part of artist's overall work activity, as well as the nature of that activity (Throsby \& Zednick, 2011). As stated by Lingo and Tepper (2013), there is

\footnotetext{
${ }^{1}$ Sofia Lindström, Linköping University, Department of Culture Studies (Tema Q) SE - 60174 Norrköping, Sweden, E-mail: Sofia.lindstrom@liu.se
} 
a need to better understand the importance of different work artists do, also nonarts work, in relation to the possibility to sustain an identity as an artist.

In studies dedicated to the working conditions of artists, work held alongside the artistic activity is often perceived negatively, as it prevents artists from dedicating themselves to art on a full-time basis (Bain, 2005; Flisbäck, 2006; Foster, 2012; Menger, 2009; Pralong et al., 2012; Throsby, 2010). However, this article will argue that negative narratives of multiple work can be contrasted by positive narratives. How then, can we understand different narrations of experiences of breadwinning work? The aim of the paper is to discuss how identity formation, work behavior, understandings of success as well as working conditions relate to either positive or negative narrations of multiple job holding. It is argued that artists whose identity and work behavior is understood according to the ideal type 'bohemian', that is, adopting an ethic of art as lifestyle and a rejection of the market, are more likely to form positive narratives of breadwinning work. Conversely, artists whose work behavior is understood as 'entrepreneurial' as they do not reject the market, although constructing their artistic identity in accordance to bohemian ethics of art as a lifestyle, are more likely to form negative narrative of breadwinning work. However, it was found that if the conditions of the breadwinning work were too insecure, such as having little or no possibility for stable employment and/ or control over work hours (c.f. Kalleberg, 2011), the artists' narration of multiple job holding will be negative regardless of artistic identity/behavior. The article will conclude by a discussion of the implications of these results for policy regarding artistic work.

\section{Artistic work and multiple job holding in Sweden}

Writers on sociology of work have described changes in the structural and institutional contexts of work in most advances economies since the 1970s, resulting in the polarization of work and a rise in nonstandard and precarious forms of labor, such as temporary work, multiple job holding, project-based work, and involuntary self-employment (Kalleberg, 2011; Standing, 2011). The understanding of artists' experiences and coping strategies of precarious work thus becomes important for the broader work force (Lingo \&Tepper, 2013) ${ }^{1}$. Compared to other workers known to have precarious working conditions, artists are predominantly middle class and have long educational years, aspects that traditionally shelter individuals from precarity (Gustavsson et al., 2012; Standing, 2011). Also, artists have been theorized as not belonging to the sphere of work or even outside society itself, with the argument that they voluntarily exclude themselves (Becker, 1997; Gerber, 2015; Oakely, 2009). The self-fulfilment and possibilities of generating meaning in creative work thus seem to function as justifications of the often precarious work experiences artists face. As artists typically find themselves in precarious conditions relating to their artistic work, the majority are in need of other, incomebringing work (Eikhof \& Haunschild, 2007; McRobbie, 2011). This other work may add to their precarious situation, which will be exemplified and discussed in this article.

In a survey regarding Swedish visual artists, $77 \%$ of the respondents were found to spend less than 40 hours or more per week on artistic work, that is, full time (Flisbäck, $2011)^{2}$. Swedish visual artists are typically 'combinators'-a term coined to describe the recourse to different employment contracts, usually mixing short-term employment and self-employment (KRO/KIF, 2014). One-third of Swedish visual artists reported having 
had at least six different employers or clients during one year (Flisbäck, 2011). One of the conclusions of the 2011 report was that the artists tried not to cut back on the hours spent on artistic work in order to supplement creative income from other types of work, but instead added more hours to their work week ${ }^{3}$. In a recent report from the Swedish Artists' Organization (KRO/KIF, 2014), the median income of artists had stagnated in the last decade and the proportion of artists who could spend more than $75 \%$ of their work hours on artistic work had dropped. Interestingly, according to Alpher and Wasall (2000), there has been little difference between the proportion of artists who work more than one job when comparing states with different support provision to artists, such as Finland and the USA (c.f. Karhunen, 1998). Sweden has a tradition of providing state support to artists through bursaries and stipends, as well as upholding important institutions such the Museum of Modern Art. As will be discussed in this article, state support to artists can encourage an artistic identity in opposition to the market.

Researchers on creative work and cultural economy such as Throsby and Zednick (2011) and Menger (1999) use a typology of artistic work, nonartistic work, or work related to art in their research on multiple job holding in the art world. This typology was used in a survey of alumni from the Royal Institute of Arts in Stockholm in order to analyze how contemporary Swedish artists differ in terms of their activities (Lindström, 2012). Seventy per cent of the alumni reported having jobs that were nonrelated to art after their graduation. Healthcare service (elderly care, handicap care), restaurant, and retail were the most common cited nonartistic sectors, work areas typically featuring low pay and little security (Flisbäck, 2011; Menger, 1999; Thörnqvist \& Engstrand, 2011). The report is illustrative of how Masters degree in Fine Arts is no guarantee of full-time artistic work.

\section{Artistic identity formation and behavior}

Work and career affects the definition of one self as it relates to behavior, motivations, personal meanings, and individual values (Bridgstock, 2013, p. 130; Kalleberg, 2011). Understanding identity in relation to work highlights how it can be understood not as a psychological term, mirroring one's inner self, but as formed in social contexts. In this section, the understanding of artists guided by 'bohemian' or 'entrepreneurial' ethics will be outlined. Consequently, each of these will be related to the context of Swedish cultural policy as well as the role of the respondent's higher education in the arts, in order to connect them to my material consisting of Swedish visual artists. In the Results section, these categories are theoretically generated as ideal types, which will be discussed in relation to different work behavior and identity found in my material, which has consequences for the narration of experiences of multiple job holding.

\section{The bohemian ethic}

Bain (2005) argues that since artist lack any shared workplace culture to develop their work identity, they learn it through myths and stereotypes surrounding the artist as a bohemian rebel (c.f. Eikhof \& Haunschild, 2007; Røyseng et al., 2007). One aspect of the bohemian ethic is to understand art as more than just having an occupation but 
merging into the individual's identity as whole (Bain, 2005). Another aspect is the perceived autonomy and distance from market demands that implies the meaning-making process of engaging in artistic work. As explored by Becker (1982), Bourdieu (1996) and Oakely (2009) artists tend to form their professional identities in opposition to economic incentives and true to the notion of art for art's sake. The often noneconomic aims and creative mission of artists are in conflict with business logic such as attracting customers (Hausmann, 2010). However, more than a myth, the autonomy of the artist and the art world can be understood as a result of the evolution of the differentiation process of society where the arts became a field in its own right, separated from the church, the state, and the economic field (Bourdieu, 1996; Luhmann, 2000). The struggle for artists is often to delimit influence of business logic in favor of artistic logics and aims (Hausmann, 2010).

In Scandinavia, the notion of the autonomy and the freedom of the arts as related to welfare has been seemingly prevalent. The Scandinavian countries largely adopted the British model of the arm's length principle in order to protect the arts from inappropriate political influence (Mangset, 2009). Swedish arts policy largely has tried to compensate for market failure regarding the arts and culture. In the 1974 goal formulations for the cultural policy of Sweden, the ideological marker 'to counteract the negative effects of commercialism' was added (Frenander, 2007). One important Swedish policy measure for improving conditions for artists has been the $1 \%$-rule, where $1 \%$ of the construction costs for new public buildings are allocated to artistic decoration. Another policy measure was the earlier guaranteed income for selected artists, removed by the center-right government in 2010 (Karlsson, 2010). Ericson (1988) compares the Stockholm artist to the New York artist, where the latter was found to work in a more careerist, calculative, and aggressive manner in order to survive. As the Stockholm art world became more cosmopolitan in the 1980s, Swedish artists started to admit that they are actively pursuing careers, which marked changing ideals from the role of the artist social revolutionary in the 1970s, rejecting the market. In contrast to the New York artists, Swedish artists tried to 'maintain the romantic image of the creative genius and has not been very willing to admit that its artists are part of a work context' (Ericson, 1988: p. 71). This bohemian ethic has until recently thus been supported by Swedish cultural policy, and as the next section will outline, as well as the higher education in the arts.

\section{Identity formation at the higher arts education}

In my previous work (Lindström, 2015), I explore how often unspoken norms and values of an arts college uphold a separation between art as vocation and art as occupation. The principal data in this study consist of interviews with artists holding an MFA from the Royal Institute of Arts in Stockholm. The Institute has a specific place in the Swedish art world insofar, as it is the oldest and most prestigious higher education establishment for visual artists. It is deemed to function as a safeguard for respectable, high-quality art in Sweden (Gustavsson et al., 2012). The collaboration between elite galleries in Stockholm and the institute has historically marked the limited access to the Stockholm art world (Ericson, 1988). In Sweden, education is important for separating professional artists from lay artists. In their work on the Swedish art world, 
Gustavsson et al. (2012) outline a strong correlation between having been a student at the institute and a successful artistic career.

Undertaking an MA in fine arts does not mean that the identification with the artist role is straight-forward. The institute was found to encourage students to identify as artists as well as to downplay issues of how to make a living as an artist. Students acknowledging art as a way to make a living (and not just a way of living) could be understood as not having what it takes to be a 'true' artist (Lindström, 2015). My respondents learned little skill and knowledge associated with artistic enterprise, such as sales and marketing, business strategy, and finance. This left above all students lacking contacts in the art world, for example, by having artist parents, feeling empty-handed. They lacked knowledge of the art world when it comes to finding work, as well as how to access networks, an issue found to be essential for career success (Bridgstock, 2013; Hausmann, 2010). As such, the arts education of my respondents largely supported an identity formation close to the formerly outlined bohemian ethic.

\section{A new ethic? Entrepreneurialism and art}

As a consequence of the nonstandard character of the artistic career, typically outplayed in networks rather than organizations, creative work arrangements tend to center on individual behavior and creativity. Artists and creative workers have been targeted as forerunners of a kind of work subjectivity that is understood as entrepreneurialmanaging one's own career progression rather than through employment, recognizing opportunity, and managing risk (Bridgstock, 2013; Gill, 2014; Pralong et al., 2012) . Diverse fields of creative and artistic work-especially the creative industries-have even been targeted by policymakers as the key to job growth, gross domestic product growth, and urban regeneration (Bridgstock, 2013; Eikhof \&Warhurst, 2013; Florida, 2002) $)^{5}$.

In Sweden, inspired by particularly British cultural policy, the former center-right government agreed on plan of action in 2009 to encourage collaboration between culture and business. The emphasis was on the cultural industries and the promotion of the understanding of artists as entrepreneurs (Tomson, 2011; Widenheim, 2012). In the new policy goal formulation from 2009 , initiated by the center-right government, the formulation to counteract the negative effects of commercialism was removed, marking a shift in the role of the state as protecting the arts from capitalist market logics.

Brigdstock (2013) describes artists as 'protean careerists'. This entails the constructing of individual career paths, as well as possessing strong personal motivations for venturing into the art world. The usual sense of the term 'entrepreneurship'-involving pursuit of profit and commercial gain—does not necessarily apply to artists: 'Put simply, artists tend to want to make art and make a living from it-business entrepreneurs tend to want to run a successful enterprise' (Bridgstock, 2013, p. 128). As a result, entrepreneurship education in the arts tends to be a controversial topic, as any commercial emphasis relation to the artist's career will be incongruent with many artists and art educator's values (Bridgstock, 2013; Hausmann, 2010). However, Eikhof and Haunschild's (2007) study of German theaterworkers points to the way a bohemian lifestyle may go hand in hand with a certain entrepreneurial self-management. The artists in Eikhof and Haunschild's (2007) study were concerned with whom and where they were seen, and 
using networking as a way to enhance employability. The commitment to the bohemian principles permitted the artists to not understand themselves as exploiters of their own person, although making personal sacrifices for work.

As previously stated, issues of how to make a living as an artist has been found to be downplayed by the higher arts education of my respondents, and courses in marketing and economy to be scarce (Lindström, 2015). Sellable art forms such as graphic design, applied arts, or even paintings can be understood to be of lesser status, while 'non-object' art forms such as installations, film, and performance are given high status. However, art students are encouraged to adopt a self-reliant behavior that entails the ability to be driven and outreaching, to manage insecurity and risk, and to be responsible for one's own trajectory, that is, being enterprising (Lindström, 2015). Following Bridgstock (2012), to be enterprising is related to the 'identification or creation of artistic opportunities and exploitation of those opportunities in terms of applying or sharing artistic activity in order to add value of some kind' (Bridgstock, 2013, p. 126). This is illustrative of how the formation a bohemian ethic does not hinder the adoption of entrepreneurial work behavior as related to this self-reliant subjectivity (c.f. Eikhof \& Haunschild, 2007). This has implications for experiences of multiple job holding, which will be explored in the Results section.

\section{Materials and analysis}

The material of this article consists of interviews with artists holding an MFA from the Royal Institute of Arts in Stockholm. All but one still reside and/or have their principal work activity in Stockholm. Regarding the interview material, the overall number of respondents is 11 women and 9 men aged 30-52 years at the time of the interviews thattook place in 2011-2013 (Table 1).

Respondents were selected with the intention to capture different experience of both artistic work and breadwinning work. Regarding their activity, only one of my respondents worked as a full-time artist and could live on his income from artistic work. Three other respondents worked as full-time artists but were reliant on the income of their spouses. Two of my respondents no longer worked as artists, one by choice and one involuntarily because of her work situation. A number of my respondents have worked as full-time artists, but for various reasons, mostly related to family, began to hold other jobs besides their artistic activity. Their experience illustrates the issue of continuation and disruption in artistic careers.

The interviews were understood as narratives in my analysis. The respondents were encouraged to 'tell their stories'-starting with their first interest and activity related to art, to their current situation, as well as their ideas and thoughts about the future. The idea was thus to understand their work experiences, and in extension their identity formation, in relation to those experiences (Andrews et al., 2008). The underlying assumption is that labor and work-even when 'nonstandard'-has continuing importance for identity work, and that individuals (re)construct themselves through the act of retelling (work) experiences (Foster, 2012; Paquette, 2012). As previously stated, artists are understood to merge their identities and their work, but may disindentify with breadwinning work (Bain, 2005). As stated in the Introduction, the analysis identified multi-faceted experiences of multiple job holding, which were largely categorized

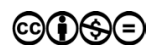


Table I List of respondents

\begin{tabular}{|c|c|c|c|c|c|}
\hline & Respondent & $\begin{array}{l}\text { Year of } \\
\text { birth }\end{array}$ & $\begin{array}{l}\text { Year of } \\
\text { graduation }\end{array}$ & Activity & $\begin{array}{l}\text { Ideal type identityl } \\
\text { behavior }\end{array}$ \\
\hline ।. & 'Katarina' & 1967 & 2000 & $\begin{array}{l}\text { Part-time breadwinning } \\
\text { work, part-time artist }\end{array}$ & Bohemian \\
\hline 2. & 'Fredrik' & 1970 & 1998 & $\begin{array}{l}\text { Part-time arts teacher, } \\
\text { part-time artist }\end{array}$ & Bohemian/entrepreneurial \\
\hline 3. & 'Josef' & 1965 & 1995 & Artist & Bohemian/entrepreneurial \\
\hline 4. & 'Frida' & 1973 & 2006 & $\begin{array}{l}\text { Nearly } 100 \% \\
\text { breadwinning work }\end{array}$ & Bohemian \\
\hline 5. & 'Gustav' & 1968 & 1995 & $\begin{array}{l}\text { Part-time arts teacher, } \\
\text { part-time artist }\end{array}$ & Bohemian \\
\hline 6. & 'Kajsa' & 1973 & 2002 & Mainly arts teacher & Bohemian \\
\hline 7. & 'Lars' & 1960 & 1996 & No longer artist & Bohemian \\
\hline 8. & 'Lisa’ & 1964 & 1996 & $\begin{array}{l}\text { Part-time arts teacher, } \\
\text { part-time artist }\end{array}$ & Bohemian \\
\hline 9. & 'Louise' & 1979 & 2008 & Student & Bohemian \\
\hline 10. & 'Helena' & 1980 & 2009 & $\begin{array}{l}\text { Artist, breadwinning work } \\
\text { on weekends }\end{array}$ & Bohemian/entrepreneurial \\
\hline 11. & 'Ulrika' & 1972 & 2007 & Artist & Bohemian \\
\hline 12. & 'Isabella' & 1981 & 2010 & $\begin{array}{l}\text { Artistic work, } \\
\text { breadwinning work, } \\
\text { unemployment }\end{array}$ & Bohemian \\
\hline 13. & 'Hannes' & 1979 & 2009 & $\begin{array}{l}\text { Designer, occasional } \\
\text { breadwinning work }\end{array}$ & Entrepreneurial \\
\hline 14. & 'Peter' & 1981 & 2008 & $\begin{array}{l}\text { Artist, breadwinning work } \\
\text { on weekends }\end{array}$ & Entrepreneurial \\
\hline 15. & 'Vera' & 1971 & 2001 & Artist & Bohemian/entrepreneurial \\
\hline 16. & 'Maria' & 1967 & 2007 & Artist & Bohemian \\
\hline 17. & 'Per' & 1969 & 2001 & $\begin{array}{l}\text { Part-time breadwinning } \\
\text { work, part-time artist }\end{array}$ & Bohemian/entrepreneurial \\
\hline 18. & 'Robert' & 1975 & 1998 & Artist & Bohemian/entrepreneurial \\
\hline 19. & 'Markus' & 1973 & 2003 & Arts consultant & Bohemian \\
\hline 20. & 'Mira' & 197| & 1998 & Arts Teacher & Bohemian \\
\hline
\end{tabular}

in more or less positive or negative experiences. These two categories will be outlined in the Results section, related to narratives of identity and behaviors regarding the respondents' work and identity as artists.

The analysis has also taken into account narrations of what Pralong et al. (2012) call 'objective' and 'subjective' career success factors (see also Hausmann, 2010). Entrepreneurial aspects of art work, such the capacity to make a living from art, to gain 
reputation, access to social networks, marketing, spatial resources (a studio, somewhere to exhibit), access to collectors, donors, and audiences are all part of 'objective' career success factors (Pralong et al., 2012). However, a lack of these factors may not hinder the individual from experiencing subjective success factors, that is, a sense of personal fulfillment in work regardless of results from more entrepreneurial and outward behavior. This may be job satisfaction relating to the actual creation of art works, or the fulfillment of a childhood dream of becoming an artist (Hausmann, 2010). In this article, subjective success is relating to an identity that is constructed in opposition to commercialism or entrepreneurialism (c.f. Bourdieu, 1996).

It is important to note that the data are in part retrospective, as the respondents were looking back on some of their experiences. However, the experience-centered approach does not imply the search for 'true' experiences or subjectivities, such as the figure of the 'true' artist. Thus, the analysis is interested in the way retrospective experiences are narrated and how these relate to identity formation and behavior. In the Results section, the chosen quotes represent either a narrative shared by the respondents or represent a more unique experience that is deemed interesting for our knowledge on creative work.

\section{Results}

The analysis clustered my respondents roughly around three ideal types relating to either bohemian or entrepreneurial ethics informing identity formation/behaviour: the bohemian artist, the bohemian identity/entrepreneurial behavior artist, and the entrepreneurial artist (see Table 1$)^{7}$. These ideal types were then used to understand positive or negative narratives of breadwinning work, explored below.

As illustrated by Table 1, the analysis found that the respondents predominantly belong to the bohemian artist category. These artists primarily narrated their artistic identity as in opposition to careerism, and did not wish to (or even strongly opposed) market-friendly behavior. These artists tended to favor conceptual art, primarily installations, and performance art. They struggled with a definition of art as separate from income-bringing work and the need for survival.

If you feel that you have to do this (art) to earn money, then I don't think it will be good, if it's supposed to be art, whatever that is. At the same time, you have to make a living, so... (Isabella).

The bohemian identity/entrepreneurial behavior ideal type artist typically narrated a strong affiliation to the idea of art as a lifestyle, that is, not something one simply does to secure income (see the above quote from Isabella); however, these artists did not necessarily mind more market-friendly behavior toward visibility and contact with customers or collectors: 'I like the running of a company (...) also to be in contact with collectors and to be part of when they hang a work in their home, you know' (Robert). These artists tended to do object art works, such as sculpture, painting, photography, and different handicraft art such as weaving and crochet objects.

The third category, the entrepreneurial artist, consisted only of two respondents, one no longer identified as an artist but as a designer. These respondents did not mind 
or even preferred working with art that was easily sellable such as design and graphic design, and formed narratives of opposition toward the low status of these art forms during their arts education. They also formed narratives relating art as work and adopted a ' $9-5$ ' behavior regarding their creative work. Although the article engages in qualitative analysis, this category is not part of the analysis, as only one identifying as an artist is deemed not enough for making sound analytical points. Also, they form different narratives regarding breadwinning work where 'Hannes' is more negative and 'Peter' is more neutral/positive ${ }^{8}$. However, the category is interesting for a discussion on how artists may form understandings of art as occupation rather than vocation.

\section{Understanding positive and negative experiences of breadwinning work through the ideal types of bohemian/entrepreneurial}

\section{Positive experiences of breadwinning work}

Lacking objective success factors does not necessarily deprive a person from feelings of subjective success (Pralong et al., 2012). This is primarily related to producing what the artist deems as quality work regardless of commercial success, that is, the bohemian ethic. One of my respondents, 'Lisa', divided her working hours between teaching at a pre-school and her studio. She worked approximately two full days in the studio. Her narrative of the positive aspects of her other work related to freedom:

\footnotetext{
What's positive about having another job, on the side, is that you can be sure you are able to make a living, then you have complete freedom to experiment in the studio and work with things that are not so commercially viable. You can achieve an enormous freedom, I feel, that is important. A form of independence, perhaps (Lisa).
}

Freedom was thus constructed in relation to opening up time for artistic work and the escape from the imperative of producing sellable art work. Lisa did not exhibit her work, as she was not working with a gallery. Thus, Lisa concentrated on the actual work process in the studio, not on more entrepreneurial aspects related to artistic work, such as creating a professional network to be more visible. Lisa had been awarded state bursaries for her work, which functioned as a recognition of her work outside the realm of the market. Bursaries thus allow artists to assume a stance of indifference toward markers of career success derived from the market (c.f. Foster, 2012). Lisa's work at the pre-school functioned as a way to achieve the focus and ability to work artistically as she desired. In contrast, respondents who worked as full-time artists reflected on the un-freedom of having to seek funds for projects and thus adapt their work to target funding schemes.

'Lars' also illustrated the way in which the identity work of an artist could be constructed against 'objective career success' criteria. Lars decided to stop working as an artist, as it became 'like a job' to him: his objective career success doing exhibitions made it necessary for him work in the studio from nine to five, which made him ultimately lose 'the pleasure' in working. To him, work and art were understood as two separate entities: 
SL: You said you were trying to separate artistic work and wage labor?

Lars: Oh yes, they have always been two, two separate worlds in some way, I was offered temporary positions as an [arts] teacher, especially five or six years after [arts institution]. They said "Can you substitute for me?” Then I would say "no way," I chose other things that have nothing to do with art, preferably as far away from the art world as possible.

The separation of art and work thus not only hindered the artists from forming detrimental narratives of breadwinning work, but could also imply feelings of alienation when 'art' became 'work'. At the time of the interview, another respondent, 'Gustav', sold his work at a high enough price to make a living from it. Yet, he considered himself incapable of producing work fast enough for reasonable annual income. When working in the studio, Gustav evoked the stress that stemmed from the necessity to quickly produce works for exhibitions in order to sell. It led him eventually to 'hit the wall, so to speak'. He mentioned his ever-increasing stress over money, and how the sense of slow production overly affected his well-being. As with Lisa, Gustav's teaching work enabled him to produce works of art under less pressure to produce art work that sells, as the income from that work provided security.

These respondents expressed different needs enhanced by the breadwinning work; most commonly, 'positive' narratives were constructed as independence from the pressure of selling and producing art for visibility. Thus, they were involved in the creation of an artistic identity that positioned them as autonomous from commercial, 'objective' success, or entrepreneurial behavior. This bohemian identity also entailed the understanding of art as something more than work but as a lifestyle. However, the respondents whose narratives of breadwinning work were more positive seemed to also experience some degree of artistic success or recognition that allowed them to identify as professional artists rather than lay artists.

\section{Negative experiences of breadwinning work}

Most of my respondents with more negative experiences of breadwinning work claimed it to be a necessity in order to survive. 'Hanna', articulated that it might be understood as a mark of failure: 'I searched for breadwinning work which you have to do, I did not want to, it is a kind of resistance, it's like you think it is a great failure to take that shit job.' Hanna narrated her identity strongly in accordance to the bohemian idea of art as merging into her identity ('it's all about what kind of life I actually want to live, it's not just a job, it's a way of life, it is a lifestyle, I realize that this is something I will keep doing until I die'); however, her work behavior was categorized as entrepreneurial, as it was geared toward objective career success: she emphasized the importance of being self-employed, earning income as an artist and related success to exhibitions and the visibility of her work. The common use of phrases such as 'crappy work,' 'shit work', and 'stupid jobs' was illustrative of the incongruence between the bohemian/entrepreneurial respondents understanding of themselves as skilled artists, with the ambition to work artistically full time, and the often unskilled character of their breadwinning work.

A common narrative among the respondents regards the disappointment they expressed regarding their higher education failing in functioning as an asset when 
applying for work. During her student years, 'Kajsa' figured she would probably need to work extra after her graduation. Yet, she expressed feelings of disappointment, as she was unable to valorize her education on the labor market:

I knew what to expect, but still. It's this feeling you get when you've been in a context where you have been given recognition, where you were appreciated and uplifted, as in "you, who managed to get in, this is the best arts institute in Sweden," and then when you become confronted with the labour market, it's not worth anything anymore, and you get that feeling—something happens to you (Kajsa).

Thus, the prestige of the Royal Institution of Art formed part of why negative experiences of the labor market occurred (Lindström, 2015).

\section{The insecurity of the breadwinning work}

In sociology of work, the definition of 'good' and 'bad' work relates to issues of wages, benefits, control over work hours and work activities, as well as control over the termination of the job (Hesmondalgh \& Baker, 2011; Kalleberg, 2011). The issue of control over work hours was illustrated by 'Veras' narrative. She previously worked part-time at a company switchboard while trying to uphold her artistic career. At the time of the interview, Vera worked as a full-time artist but was largely supported by her husband, an engineer. Her decision to stop working at the switchboard job occurred when her work conditions changed:

\footnotetext{
It was an important job, you were important! At first we were told it was important to do things right, but later the focus was not on doing things right but on switching many people. You were not important anymore. The work tempo became hysterical. You were no longer guaranteed the hours you had had. They started calling the same day: "Can you come in for work?" (Vera).
}

The changes in the organization of Vera's other work thus made her loose her sense of control and feeling of importance regarding her job assignments. The purpose of Vera's job was to secure income, but the pay was considered too low to justify the time and energy spent there. The importance of Vera's experience lies in the deteriorating conditions of her breadwinning job affecting her experience, rather than her work identity. Vera shares the experience with others of the respondents of working in low paid jobs while trying to maintain their artistic work, calling it the 'vicious cycle' of having to work long hours to make ends meet (c.f. Flisbäck, 2011).

Other respondents spoke of the insecurities of their breadwinning work by never knowing how long they are going to be able to stay at their work place. 'Markus', who worked for a state institution, was earlier employed but is now hired by the same employer as self-employed:

I know that I have two more years. And then I can probably ... apply for the job again. But then it's an open procurement so you can't be sure to get it at all. It depends ... it depends on what you demand, you know, in terms of cost (Markus) 
The breadwinning work may provide the artists with little reward and hinder them from engaging in artistic work. The breadwinning job, when spoken of as detrimental, was often perceived as a repeated interruption of the concentration needed to work as an artist, and, in a broader sense, as a repeated interruption of one's career.

Thus, it is possible to roughly understand the respondents narrating negative experiences of the breadwinning work as constructing art and themselves as artists in less opposition to entrepreneurial behavior and in accordance to more 'objective career success factors', such as the ability to be visible and to be able to live on one's artistic work. However, they narrated a strong affiliation to the bohemian ethic of art as a way of life. Their identity as professional, trained artists was hurt by taking breadwinning work that had little relation to art. However, the conditions of the breadwinning work also need to be taken into account when understanding negative narratives. Artists who experienced low control over work hours, insecurity regarding future employment, and low pay would not form positive narratives of their breadwinning work regardless of identity or behavior. The need undermined by the 'bad' breadwinning work was above all the ability to form continuity in artistic career and work.

\section{Discussion}

The aim of this article was to outline the importance of identity formation and behavior together with working conditions when understanding different narrations of narratives on multiple job holding among of Swedish artists. According to Umney and Kretsos (2014), a labor process inspired analysis of creative labor must ask how it enables participants to pursue their own artistic objectives. To my respondents, this was always the issue at stake in relation to breadwinning work. However, not all had the same idea of what their artistic objectives or identities were, and how to behave in order to meet them.

Common sense would tell us that artists with a degree from a higher education in the arts will form detrimental experiences of breadwinning work, as it hinders their ambition to work full time as professional artists. However, this article argues that the understanding of how breadwinning work functions is dependent on artists professional behavior and identity as according to either a more 'bohemian' or a more 'entrepreneurial' identity category ideal types. These categories can be understood in relation to different definitions of career success. 'Subjective' success is related to a more bohemian behavior where the core interest as an artist lies in the ability of creation free from market pressure. Conversely, 'objective' success is defined in relation to more entrepreneurial behavior as securing access to networks, spatial resources for visibility (a studio, an exhibition venue), pursuing actively to be able live out of one's own artistic production. Roughly, the artists that construct positive narratives of their breadwinning work construct their work identity in opposition to entrepreneurial behavior, sometimes enough to completely separate art from work. For them, the breadwinning work can enhance their ability to work and identify as autonomous artists. Thus, these artists will rather have multiple jobs than adopt an entrepreneurial, careerist behavior. This result mirrors the context of Swedish arts education and cultural policy traditionally encouraging an artistic subjectivity as autonomous, especially from the market.

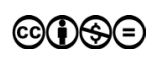


However, artists can strongly adhere to bohemian ethics as defined as viewing art as a lifestyle, merging into the identity of the artist (something one is, not just something one does), and form narratives positive to self-employment and business. These artists do not necessarily reject the market, but may display entrepreneurial behavior such as outreaching behavior in order to be more visible, engage in contacts with buyers, or do occasional commercial work. Although it has been found that the Swedish art world turned more market-friendly in the 1980s (Ericson, 1988), this reflects a more recent cultural policy discourse on the importance of cultural business and arts entrepreneurialism, as well as the encouragement of an enterprising, self-reliant subjectivity by the higher arts education that functions alongside the bohemian ethic. When the careers of these artists do not meet the objective success criteria, their dissatisfaction is related to their inability to translate their educational capital into a position-be it on the regular labor market or in the art world. Even if they hold an MFA from a prestigious arts college, they find themselves unable to build a proper professional identity. For them, the issue is to avoid multiple job holding and to adopt behavior that enables them to make a living out of their art. These artists would benefit from a greater effort from the higher education in the arts to include preparation for entrepreneurial skills and knowledge on sector-specific rules in order to enhance employability, such as explored by Bridgstock (2013) and Hausmann (2010) .

For artists avoiding commercialism and entrepreneurialism, the issue of multiple job holding will be the ability to find income bringing work and employment that is nonexploitable and stable enough to open up space for energy and time spent on their art works. When these requirements are met, having a 'day job' enables the artist to form an identity true to their values and to form work continuity. However, if the breadwinning work offers little but added insecurity that drain the artist of energy and interrupts their artistic work, they will not form positive narratives of it regardless of their work identity. Thus, the analysis also reveals the importance of the working conditions of the breadwinning work. Some of my respondents experience severe insecurity and are sometimes even exploited for their breadwinning work. Both professional identity and working conditions were thus found to be important for understanding how individuals holding multiple jobs understand and narrate their work experiences.

Relating to the common narrative of my respondents' difficulty in finding stable breadwinning work are sociological theories of labor markets becoming more polarized, precarious, and insecure (Kalleberg, 2011; Standing, 2011). Although the artistic career hasalways entailed a great deal of risk, artists also face precarious conditions in their breadwinning work. As an example, one of my respondents worked on a temporary contract for 12 years for the same employer before being employed on a permanent contract, which is against Swedish labor law. Any deterioration of work conditions in typical breadwinning work sectors such as healthcare and retail is a concern to workers who wish to enter these as a means to some material security and autonomy. It is an issue beyond merely visual artists but any categories frequently taking breadwinning work, such as students, musicians, and actors. Policy interested in artist's working conditions should thus be interested in strengthening general labor rights. A major contributing factor to having positive experiences of multiple job holding lies in the artist's relative control over when and how much they can work to adapt their breadwinning work to their artistic work. Rather than temp jobs, 'bohemian' artists can arguably benefit from part-time stable employment to make possible the continuation of their artistic work. 
Labor legislation changes, such as the 2007 employment category 'general temporary employment' (where Swedish employers are no longer entitled to declare any reason for employing on temporary contract, see Government proposition, 2006/07), are problematic in this case. Due to the results of this study pointing to the interrelation between different kinds of work, I argue that this is an issue worthy of attention as much as any exploitative characteristic of creative work explored by researchers, such as Dex et al. (2000), Gill (2014), Eikhof and Warhurst (2013), and Siebert and Wilson (2013).

As artists have used multiple job holding as a strategy for upholding their artistic work for long, their experiences hold interest in the context of such nonstandard work situations being predicted to become more common in the general work force. This study adds to our knowledge on the strategies of artists and the interconnection between the different types of work they are engaged in.

\section{References}

Alpher N, and Wasall G. (2000) More Than Once In a Blue Moon: Multiple Job Holdings by American Artists. Research Division Report \#40, Santa Ana: National Endowment for the Arts.

Andrews M, Squire C and Tamboukou, M. (2008) Doing Narrative Research. London: SAGE.

Bain A. (2005) Constructing an Artistic Identity. Work Employment \& Society, 19 (1): 25-46, doi: http://dx.doi.org/10.1177/0950017005051280.

Becker H. S. (1982) Art worlds. Berkeley: University of California Press.

Bourdieu P. (1996) The Rules of Art: Genesis and Structure of the Literary Field. Cambridge: Polity Press.

Bridgstock, R. (2013). Not a dirty word: Arts entrepreneurship and higher education. Arts and Humanities in Higher Education, April/July 2013; vol. 12, 2-3: pp. 122-137, doi: http://dx.doi.org/10.1177/1474022212465725.

Dex S, Willis J, Paterson R and Sheppard E. (2000) Freelance Workers and Contractual Uncertainty: The effects on Contractual Changes in the Television Industry. Work, Employment \& Society, 14 (2): 283-305, doi: http://dx.doi.org/10.1177/ 09500170022118419.

Eikhof DR and Haunschild A. (2007) For Arts Sake! Artistic and Economic Logics in Creative Production. Journal of Organizational Behavior, 28: 523-538, doi: http:// dx.doi.org/10.1002/job.462.

Eikhof DR and Warhurst C. (2013) The promised land? Why Social Inequalities are Systemic in the Creative Industries. Employee Relations, 35 (5): 495-508, doi: http://dx.doi. org/10.1108/er-08-2012-0061.

Ericson D. (1988) In the Stockholm Art World. Academic dissertation, Stockholm studies in social anthropology. Stockholm: Stockholm University.

Flisbäck M. (2006) Att lära sig konstens regler: en sociologisk studie av osäkra framtidsinvesteringar [Learning the rules of art. A sociological study of risky investments in the future]. Göteborg: Department of Sociology, Göteborg University.

Flisbäck M. (2011) Konstnärernas inkomster, arbetsmarknad och försörjningsmönster [Artist's income, labour market and patterns of making a living]. Stockholm: Konstnärsnämnden.

Florida R. (2002) The Rise of the Creative Class: and How it's Transforming Work, Leisure, Community and Everyday Life. New York: Basic Books.

Foster K. (2012) Work, Narrative Identity and Social Affiliation. Work, Employment \& Society, 26 (6): 935-950. doi: http://dx.doi.org/10.1177/0950017012458024. 
Gerber A. (2015) Art Work? Tradition, Rationalization, and the Valuation of Contemporary Artistic Practice. Diss. Department of Sociology, New Haven: Yale University.

Gill R. (2014) Unspeakable Inequalities: Post Feminism, Entrepreneurial Subjectivity, and the Repudiation of Sexism among Cultural Workers. Social Politics, 21 (4): 509-528, doi: http://dx.doi.org/10.1093/sp/jxu016.

Gustavsson M, Börjesson M and Edling, M. (eds 2012). Konstens omvända ekonomi: tillgångar inom utbildningar och fält 1938-2008 [The reversed economy of the arts. Assets in education and field 1938-2008]. Göteborg: Daidalos.

Hausmann, A. (2010) German artists between bohemian idealism and entrepreneurial dynamics: reflections on cultural entrepreneurship and the need for start-up management. International Journal of Arts Management, 12 (2), pp. 17-29.

Kalleberg, AL (2011) Good jobs, bad jobs. The Rise of Polarized and Precarious Employment Systems in the United States, 1970's to 2000's. A Volume in the American Sociological Association's Rose Series in Sociology. New York: Russel Sage Foundation

Karlsson, D. (2010). En kulturutredning: pengar, konst och politik [A culture investigation; money, art and policy]. Göteborg: Glänta produktion

Karhunen P. (1998) Labour market situation of graduated artists, in Heikinnen and Koskinen, (eds) Economics of Artists and Arts Policy, Helsinki: Arts Council of Finland.

KRO/KIF (2014) Utsikt frän ateljéerna [A view from the studios]. Survey report May 2014. Stockholm: KRO/KIF.

Lindström, S. (2012) När friheten sätts på prov - en undersökning av examinerade studenter frän Kungl. Konsthögskolan 1995-2009 [When freedom is put to the test - a study of alumni from the Royal Institute of Arts 1995-2009] Stockholm: The Royal Institute of Art.

Lindström, S. (2015) Constructions of Professional Subjectivity at the Fine Arts College. Professions \& Professionalism, 5(2), doi: http://dx.doi.org/10.7577/pp.869.

Lingo, EL and Tepper, SJ. (2013) Looking Back, Looking Forward: Arts-Based Careers and Creative Work. Work and Occupations, 40 (4), pp. 337-363, doi: http://dx.doi. org/10.1177/0730888413505229.

McRobbie, A. (2011) Re-Thinking Creative Economy as Radical Social Enterprise. Derived from http://www.variant.org.uk/41texts/amcrobbie41.html.

Menger P-M. (1999) Artistic Labour Markets and Careers. Annual Review of Sociology, 25: 541-574, doi: http://dx.doi.org/10.1146/annurev.soc.25.1.541.

Oakely K. (2009) From Bohemia to Britart - art students over 50 years. Cultural Trends, 18(4): 281-294, doi: http://dx.doi.org/10.1080/09548960903268105.

Paquette J. (ed 2012) Cultural Policy, Work and Identity: the Creation, Renewal and Negotiation of Professional Subjectivities. Farnham, Surrey: Ashgate.

Pralong J, Gombault A, Liot F, Agard J-Y and Morel, C. (2012) Unpacking Unsuccess. Sociocognitive Barriers to Objective Career Success for French Outsider Artists. In Mathieu, C (ed) Careers in Creative Industries. New York: Routledge.

Regeringens Proposition 2009/10:3, Tid för kultur. [Government proposition 2009/10:3, Time for culture] Avaliable at: http://www.regeringen.se/contentassets/5afd $813 \mathrm{ffae}$ 94dae91e9db0f8725c3b6/tid-for-kultur-prop.-2009103.

Siebert S. and Wilson F. (2013) All Work and No Pay: Consequences of Unpaid Work in the Creative Industries. Work, Employment \& Society, 27(4): 711-721, doi: http://dx.doi. org/10.1177/0950017012474708.

Taylor S. and Littleton K. (2012) Contemporary Identities of Creativity and Creative Work. Surrey: Ashgate.

Throsby D. (2010) The Economics of Cultural Policy. Cambridge: Cambridge University Press.

Throsby D. and Zednick A. (2011) Multiple Job-Holding and Artistic Careers: Some Empirical Evidence. Cultural Trends, 20 (1): 9-24, doi: http://dx.doi.org/10.1080/09548 963.2011.540809. 
Thörnquist A and Engstrand Å-K. (eds 2011) Precarious Employment in Perspective. Old and New Working Conditions in Sweden. Work and Society no. 70, Brussels: P. I. E. Peter Lang.

Tomson K. (2011) Att Skapa en Upplevelseindustri [To create an experience economy]. Nordic Journal of Cultural Policy, 14: 71-99.

Umney and Kretsos, L. (2014). Creative labour and collective interaction: the working lives of young jazz musicians in London. Work, Employment \& Society, 28(4), 571-588, doi: http://dx.doi.org/10.1177/0950017013491452.

Widenheim C. (2012) A Recidency as Workplace. In: Widenheim C, Rosendahl L, Massuci M, Enqvist A and Habib Engqvist, J (eds) Work Work Work. A Reader on Art and Labour. Stockholm: The Swedish Arts Grants Committee/Iaspis.

\section{Notes}

1 Although this development has to some extent been mitigated in Sweden by the social security system, forms of casual and precarious work have become more common since the 1990s (Grönlund, 2004; Thörnquist \& Engstrand, 2011).

2 By Swedish law, a work week includes 40 hours; however, according to most collective agreement, full-time work is defined as 35 hours per week including holidays and weekends (Flisbäck, 2011).

3 In a survey on multiple job holding among American artists, Alpher and Wasall (2000) found the main reasons for multiple job holding to be the ability to pay for regular household expenses, reduction of unemployment risks, and acquiring skills and contacts unavailable in the primary job.

4 However, the notion of the individualistic entrepreneur must be framed in understandings of structural changes of the social context of these workers. Gill (2014) argues that laboring subjectivities are not accidental but produced by the laboring conditions themselves. Sociological literature has demonstrated that artist's careers are far from being only determined by individual skill and talent, but are embedded in socially constructed contexts (Becker, 1982; Bourdieu, 1996). For example, Eikhof and Haunschild (2007) discuss how internal and external labor markets and temporary employment contracts put actors under high pressure to be employable, why they showed high degrees of market-orientation and blurring of the work-life boundary in favor of work.

5 For an overview of the policy interest and investments in the cultural industries in Sweden, see Tomson (2011).

6 Ideal types are meant to capture general patterns in the material. See Taylor and Littleton (2012) on the varied and often conflicting views on what it means to be creative among UK artists.

7 Their different attitude can be related to family; Peter, who was planning a family with his girlfriend, accepted breadwinning work as it enabled a secure income. Hannes did not plan for a family and narrated breadwinning work more in the line of taking 'shit jobs.'

8 It is important to note that even if the analysis has categorized these artists as entrepreneurial for the sake of explanatory power, the key concern for them was to create qualitative art works, not to create successful businesses. However, they do not necessarily narrate the market as in opposition to this ambition. 